\begin{tabular}{c} 
Volume and Issues Obtainable at Center for Sustainability Research and Consultancy \\
Journal of Business and Social Review in Emerging Economies \\
ISSN: 2519-089X (E): 2519-0326 \\
Volume 5: No. 1, June 2019 \\
JSRᄃ \\
Journal homepage: www.publishing.globalcsrc.org/jbsee \\
\hline
\end{tabular}

\title{
An Assessment of the Roles and Challenges of Civil Society Organizations on the Process of Democratic Consolidation of Nigeria's Fourth Republic
}

\footnotetext{
${ }^{1}$ Musa Kabir Umar, ${ }^{2}$ Muhammad Ainuddin Iskandar Lee bin Abdullah, ${ }^{3}$ Kamarul Zaman bn Hajj Yusouf

${ }^{1} \mathrm{PhD}$ Scholar, Department of Political Science, School of International Studies, Ghazali Shafie Graduate School of Government and International Studies, University Utara Malaysia/ Lecturer, Department of Political Science, Umaru Musa Yar'adua University Katsina-Nigeria kabirbumarmusa@gmail.com

${ }^{2}$ Lecturer, Department of Political Science, School of International Studies, Ghazali Shafie Graduate School of Government and International Studies, University Utara Malaysia, ainuddin@uum.edu.my

${ }^{3}$ Lecturer, Department of Political Science, School of International Studies, Ghazali Shafie Graduate School of Government and International Studies, University Utara Malaysia, kzaman@uum.edu.my
}

\begin{tabular}{l}
\multicolumn{1}{c}{ ARTICLE DETAILS } \\
\hline History \\
Revised format: May 2019 \\
Available Online: June 2019 \\
\hline Keywords \\
Civil Society Organizations, Civil \\
Society, Democratic \\
Consolidation, Democracy, \\
Democratization Process, Politics
\end{tabular}

JEL Classification:

D20, D29, P26, P29

\section{ABSTRACT}

This paper investigated the roles and challenges of civil society organizations (CSOs) in the democratic consolidation of Nigeria. As the third sector, civil Society is known to be at the forefront in the democratization process for quite a long period of time, but their contributions are continuously being relegated especially by the state who viewed them with negative lenses particularly when they are opposed to their conducts. The paper had therefore tried to examine three civil society organizations namely Centre for Democracy and Development (CDD), Alliances for Credible Elections (ACE) and Stakeholder Democracy Network (SDN).

It achieved this objective by using a qualitative semi-structured face to face interviews supported with secondary sources of data. Nvivo 12 software was used in coding, categorization and general management of data.

The study revealed that CSOs in Nigeria have promoted the reliability of election by observing every phase of the country's electoral process. Indeed, the CSOs have promoted democratic principles of civic participation, political engagement and tolerance among some political parties thereby advancing democratic consolidation in the polity. They have also stimulated policy changes in some crucial socio-economic policies. Again, the study revealed that CSOs faced economic problems which seriously distresses their operations and sustainability especially inability to extend into rural areas. It has also shown donor organization influence on the organizations which encroach their ideological base.

The paper concluded by suggesting that the civil society must devise a means of economic survival as well as further strengthen their capacity through training and retraining to fully understand how governments operate for effective and concrete criticisms that would enhance democratic productivity to the people. Civil society should be allowed to freely ventilate democratically without threats from the state since it inspires governments to be more accountable, transparent, honest and responsive to the public needs, which will make it further win the support of the public hence reinforce its legitimacy.

(C) 2019 The authors, under a Creative Commons Attribution- 
Corresponding author's email address: kabirbumarmusa@gmail.com

Recommended citation: Umar, M. K., Abdullah, M. A. I. L. B. and Yusouf, K. Z. B. H. (2019). An Assessment of the Roles and Challenges of Civil Society Organizations on the Process of Democratic Consolidation of Nigeria's Fourth Republic. Journal of Business and Social Review in Emerging Economies, 5 (1), 125-134

DOI: $10.26710 /$ jbsee.v5i1.552

\section{Introduction}

Before the re-emergence of democratic rule in 1999, civil society organizations (CSOs) are mostly believed to be significant only against military regimes ( Kopecky \& Spirova 2008), hence overlooked during democratic regimes (Brack \& Weinblum, 2011). Immediately after the entrenchment of democracy it was later observed that the CSOs are inextricably linked with the process of democratization and would forever remain relevant for democratic consolidation (Igbokwe-Ibeto, Ewuim, Anazodo \& Osawe, 2014). Indeed, democratic consolidation has been a phrase bedevilled with so much ambiguities, as it defied a singly acceptable meaning because of contextual distinctions as what constitutes a consolidated democracy might not necessarily be so in another setting. Nevertheless, the most prominent and frequently applied sense of the phrase is the eight criteria outlined by Robert Dahl in his influential book Polyarchy. The criteria are: the right to vote; the right to be elected; right of political leaders to compete for support; free and fair elections; freedom of expression; alternative sources of information; freedom of association; and public policy institutions depending on votes and expressions of preference (Dahl, 1971). Thus, CSOs are instrumental mechanisms for making these criteria to fruition in democratic societies particularly the developing ones. It is, however, important to note that even though civil society has no single meaning in social sciences literature (Mercy, 2012; Igbokwe-Ibeto, Ewuim, Anazodo \& Osawe, 2014), yet it has been used by several political philosophers, such as Hobbes, Locke, Montesquieu, De Tocqueville, Hegel, Marx, and Gramsci (Zaidise, 2004). Diamond (1994) argued that civil society is an important mechanism for checking the excesses of democratic régimes, scrutinizing their possible abuses and violations of the law, and subjecting them to public scrutiny. Hence, a vibrant civil society is an additional essential ingredient for bringing, consolidating and maintaining democracy. According to Nuhu (2011) numerous studies have been more attentive on democratization process leaving behind the issue of democratic consolidation. However, very minute knowledge is known by which different CSOs contribute to democratic consolidation and the challenges they faced in Nigeria despite their immense role in bringing about democracy in the country (Igbokwe-Ibeto, Ewuim, Anazodo \& Osawe, 2014), though Hegel viewed some CSOs as actors of downplaying democracy (Mercy, 2012). The big questions that concerned this study are: what role civil society organizations play in the democratic consolidation in Nigeria? What are the challenges faced by the CSOs in Nigeria? It is important at this juncture to note that country (Igbokwe-Ibeto, Ewuim, Anazodo \& Osawe, 2014) have distinguished two main categories of CSOs in Nigeria namely: those that are made up of organizations whose purpose is extending the borderline of liberal democratic practices and pressure groups whose actions indirectly improve the development of democracy though their main focus is on the pursuit of own interests.

Beginning from this observation, the key objective of this paper is to have a new viewing platform by exploring the roles and challenges of CSOs in a country bedevilled with poverty, corruption, ethno-religious crisis and other socio-economic and political problems which are antithetically parallel to the principles of democracy. Thus, the study restricted itself to three selected CSO's in Nigeria namely Centre for Democracy and Development (CDD), Alliances for Credible Elections (ACE) and Stakeholder Democracy Network (SDN). It also analyses how these CSOs autonomously impacted the country's democratic consolidation process between in the Fourth Republic. Following the introduction, the paper dealt with operational definition of concepts. The third part of the paper dealt with the methodology, the fourth segment dwelled on the discussion of findings and the final part dealt with conclusion and recommendations.

\section{Conceptual and Theoretical Issues \\ 2.1 Democratic Consolidation}

Democratic consolidation is a concept which denotes democratic continuity with certain features which includes popular legitimacy, diffusion of democratic values, party building, stabilization of electoral rules, decentralization of state power, judicial reform, alleviation of poverty, elimination of authoritarian enclaves, the organization of functional interest and economic stabilization (Schedler, 1998). Contemporary realistic studies on democratic consolidation more often than not follows two strategies to understand what the notion entails i.e. the substantive and prospective approaches (Svolik, 2015). The substantive approach focuses attention on a set of results to be observable in a well-entrenched democracy and then weigh the degree at which democracy satisfies them. Such 
attractive results often consist of strong political opposition, energetic civil society, and popular acceptance of key democratic principles among the general populace. Additionally, the second, potential approach principally links consolidation with the stability of democracy (Svolik, 2015). Equally important, is the argument of Usman cited by Ibietan and Ajayi (2015) where on cautionary note argued that changing over to a democratic form of governance is not an automatic certification for democratic consolidation. To them, democratic consolidation involves refining the democratic institutions and interactions between and among political actors. There is therefore, the tendency to link democratic consolidation with profound unlikelihood of democratic collapse. It is, therefore, pertinent to note that scholars have differing views on the definition of democratic consolidation. One is a "minimalist conception," emphasizing procedural or formal democracy. The other is a "maximalist conception," focusing on the outcomes of politics, such as institutionalization of political institutions, social justice, and economic equality (Lee, 2007). The minimalist conception of a consolidated democratic regime viewed it as the process of transforming the arrangements, prudential norms, and solutions that have emerged during the transition into relations of cooperation and competition that are reliably known, regularly practiced, and voluntarily accepted by those persons or collectives that participate in democratic governance (Schmitter, 1992; Aduku \& Umoru, 2014). In the same vein, Aduku and Umoru (2014) highlights that democratic consolidation implies the internationalization of democratic culture and the institutionalization of democratic best practices by a country that has successfully embarked on a democratic transition. In its positive formulations, this branch of consolidation studies speaks about the goal of reaching democratic continuity, maintenance, entrenchment, survival, permanence, endurance, persistence, resilience, viability, sustainability and irreversibility. By contrast, negative formulations call upon the inevitability of moving beyond states of "non-consolidation," democratic fragility, instability, uncertainty, vulnerability, reversibility and the threat of breakdown. For all differences in nuance, the unifying purpose beneath this multifaceted vocabulary is straightforward. In biological metaphors: It is basically preoccupied with keeping democracy alive, with preventing its "rapid death" (O'Donnell, 1992). In this paper, democratic consolidation is referred to as the persistence and stability of democracy and its principles.

\subsection{Civil Society}

The World Bank (2013) translates the phrase civil society as a large group of non-governmental and non-profit making organizations that exist in public life, projecting the interests and values of their members or others, based on principled cultural, political, scientific, religious or philanthropic considerations. In other words, it is also construed to mean non-governmental entities such as community groups, non-governmental organizations (NGOs), labour unions, indigenous groups, charitable organizations, faith-based organizations, professional associations, and foundations. According to Markus (2001) in his focus on the development of the concept of civil society in Poland, he argued that the usage of the term civil society is constantly increasing, including other social phenomena, from associations to civility, trust to social capital which has became relevant for both present social theory and practical activities of people of various societies. Moreover, Islamoglu (2001) viewed civil society as a self-regulating, selfgoverning body outside the state which is always opposing the state, representing both societal associations expected to generate civility, social cohesion, and morality. In this discourse, CSOs denote to associations that are neither in the state nor private sector but are involved in a civic activity meant for the promotion of the interests of their members and the general society.

\subsection{Theoretical Framework}

The Liberal Democratic Theory is adopted for the paper to serve as a framework. Liberal democratic theory traces its origin and name to the European scholars of 18th century on their contributions to the streams of thoughts in the great and famous enlightenment movement. The major advocates of the theory are Voltaire, Giovanni Vico John Locke, J.J. Rousseau, John Stuart Mill, Adam Smith, Baron De Montesquieu and Thomas Jefferson former President of U.S.A among others. The theory is employed in analysing democracy and democratic consolidation because it describes the form of democracy predominant in western capitalist societies which later began to gain relevance in the peripheral capitalist societies like Nigeria.

The main features of the theory are reception of capitalist mode of production; competitive multi-party democratic system; application of the rule of law; availability of pressure groups in form of civil society organizations; separation of powers coupled with clear checks and balances; strong prominence on human rights such as freedoms of peaceful assembly; press; free and fair periodic elections; speech; free press and (Mohammed, 2013; Kwasau, 2013). Basically, liberal theory of democracy was intending to encourage citizens participation in the administrative affairs of governing societies by allowing all adult citizens the right to vote and be voted for regardless of any social status be it religion, gender, ethnicity or ownership of the means of production. The theory is therefore used 
as a framework of this analysis because it specifically outlined how democracy should behave if the process is expected to function and endure successfully. In this context, it could be seen that for the consolidation of democracy in Nigeria, the CSOs as one of the major ingredients of liberal democracy must ardently allowed to ventilate freely to ensure among other things the credibility of elections, influencing public policy and ultimately the respect of the rule of law. This can be done through various ways beginning from public enlightenment or voter education on the significance of election, checking the excesses of the elected democratic leaders and ensuring democratic productivities reached the common man. Indeed, these are some of the major arguments the theory exposed as the important factors which the CSOs are playing key role for an effective, efficient, successful and sustainable democratic consolidation.

The theory has, however, been challenged by many critics as they believed it does not respect absolute majority rule. This is because the actual power is concentrated in the hands of the few so-called representatives. Thus, Marxist scholars described it merely a class-based system of governance like oligarchy. Besides that, many scholars accused it of being too expensive particularly when it comes to elections expenditure which would have been more meaningful if spent on a productive societal project.

\section{Methodology}

The methodology employed in this paper is a qualitative approach using face to face semi-structured interview in data gathering. According to Yin (1984) and Babbie (2004) qualitative design is considered more appropriate for explanatory and descriptive researches. The choice of the qualitative design was further informed by the need to explore the perspectives, thoughts and perceptions of the relevant stakeholders and experts in CSOs and democracy, politicians and academics respectively. The study also used expert choice sampling technique by recruiting 8 informants, who are political party leaders, leaders of the three selected CSOs and an academic (an expert in civic political movements). This method is used because the informants are possessing a wide range of vast relevant expertise and experiences on the phenomenon under investigation. Secondary data in form of journal articles, newspapers, textbooks and some documentary materials from the political parties and civic organizations were used to support the interview submissions. The interview data was subjected to the managing procedures by first organizing the data, the preliminary reading of database, coding, transcribing, thematic organization, representation and forming an interpretation of them as Creswell (2013) viewed that doing such enables the researcher to present more reliable and precise results.

Table 1: The Code and the category of Informants

\begin{tabular}{|l|l|l|}
\hline Code & Interpretation & Frequency \\
\hline Informant 1,2,3 \& 4 & Civil Society Leaders & 4 \\
\hline Informant 5 & Political Party Leader & 1 \\
\hline Informant 6 & Academic & 1 \\
\hline & Total & 6 \\
\hline
\end{tabular}

Source: Field Work, 2018

The reasons for selecting these informants was because they have broad ideas and experiences in the activities of civil society organizations in their efforts to consolidate democracy in the country (Mercy, 2012). They were interviewed to get the most reliable and first-hand data on the activities of CSOs between 1999 and 2017. The data was analysed after transcription, coding, thematic organization and representation.

\section{Discussion of Findings}

\subsection{The Roles of Civil Society Organizations in Nigeria's Democratic Consolidation}

Civil society organizations are indispensable actors in a democratic enterprise as they encourage citizens democratic participation to ensure a functioning and healthy democracy (Jamali S., Hasan, H. \& Ching, L.C., 2016). To some degree their contributions in terms of consolidating democracy supersedes political parties particularly in Nigeria. The diagram below shows the informants who responded on the contributions of CSOs towards democratic consolidation in Nigeria. 


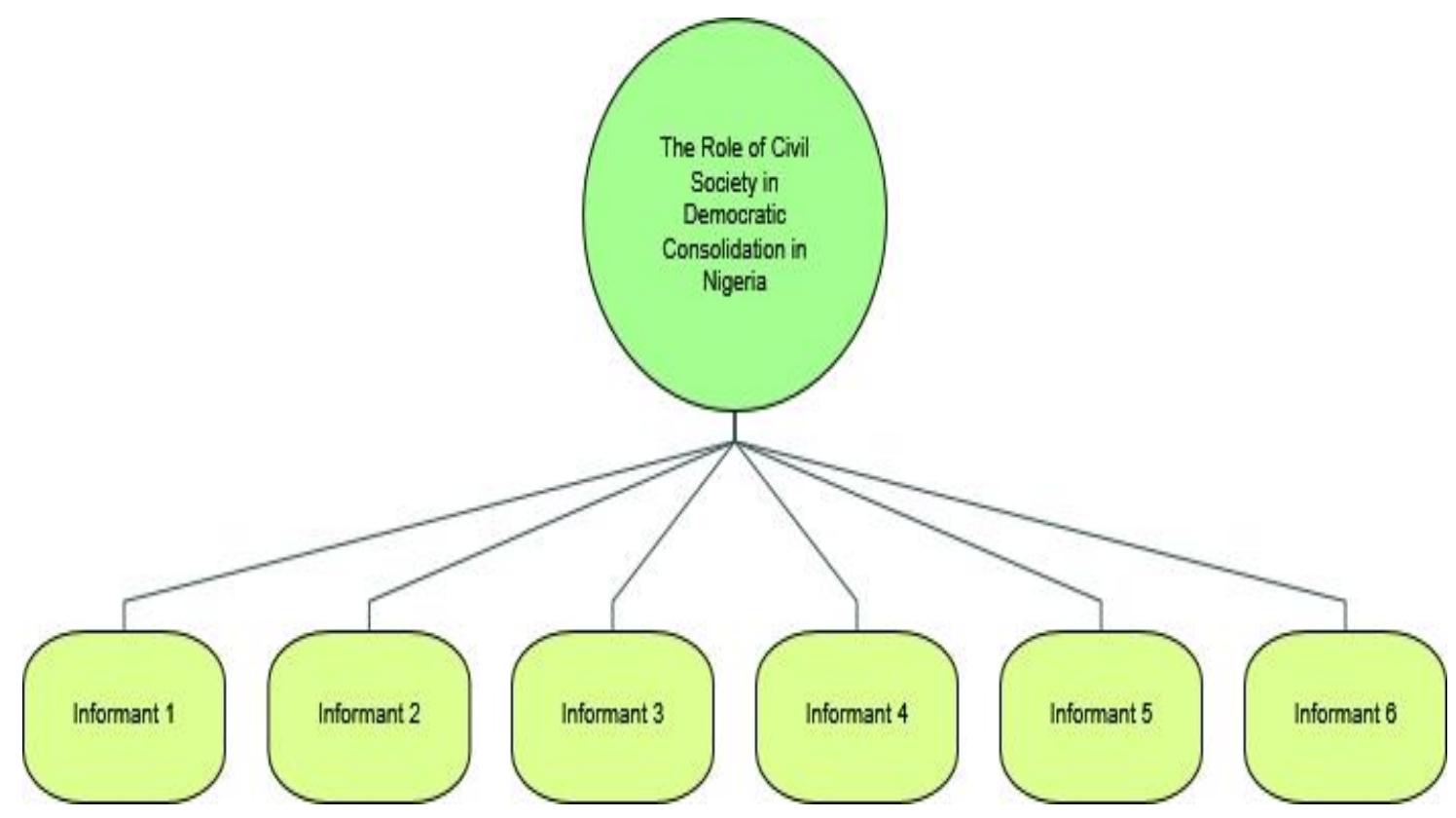

Figure 1. Diagram Showing the Informants who Responded on the Roles of CSOs in Democratic Consolidation in Nigeria

Source: Nvivo 12

The role of civil society organizations become more pronounced especially in the developing societies of Asia, Africa and Latin America where immediately after their independence the military toppled their bequeathed democratically elected governments and hold onto power for many decades. This powered the emergence of civil associations with pro-democratic agendas to start agitating rigorously for the entrenchment of democratic rule. Informant 4 and 6 have argued that civic associations have been the major players in the Nigeria's democratic process since during the military. They further lamented that, CSOs were the actors that pressured the military to go back to their respective barracks for their constitutional responsibilities thereby paving the way for the reemergence of democracy in Nigeria. Informants 2 and 3 argued that, at all levels, civil society organizations play significant roles in democratic processes up to the end of deepening or consolidating it in the system. Indeed, the role of civil society in deepening democracy is tremendous as Thapa (2016) points out citing Stephan and Linz (1996) who reasoned that a strong civil society is necessary in the beginning of democratic transition through its consolidation (Mercy, 2012). This is in line with the liberal democratic theory postulation that the CSOs are crucial agents in monitoring the process of elections in Nigeria. They enlighten the public on civic responsibilities such as monitoring elections. In fact, the chief functions of CSOs in democratic consolidation is ensuring credible elections; guarding against democratic threats; influencing public policy; responding to and empowering citizens through advocacy programs such as voter education among others (Mercy, 2012). Through advocacy these CSOs generally interrogate the way in which policy is directed and partake in the agenda setting as to raise important issues that would eventually strengthen the democratic processes (Igbokwe-Ibeto, Ewuim, Anazodo \& Osawe, 2014; Botchway, 2018). The liberal democratic theory has strongly explained the greater need of the activities of pressure groups in form of CSOs on governmental policy influence for the betterment of the citizenry and which affect the continued survival of the democratic process. Indeed, informants 1 and 6 has averred that CDD, ACE and SDN have been very agile in promoting democracy through an all-inclusive approach in any aspect of Nigeria's democratic process. These associations recommend policy answers to the democratic regime and ultimately open the space for public argumentation. For example, these CSOs works in various areas such as constitutional and electoral reforms programs in Nigeria which strongly helped in the consolidation the nascent democracy. Additionally, the CSOs engage in pushing for policy options preferable to them or which they go against which in turn influences positively in consolidating democracy in the country. They do this through various events such as conferences, media campaigns, workshops, seminars among others (Bocthway, 2018). In fact, in Nigeria the CSO's have been the voice of the poor especially when an unwanted policy is about to be put in place. Accordingly, apart from giving citizens respect for the state and positive engagement, vigorous civil societies play an immeasurable roles towards democratic consolidation by enhancing the accountability, responsiveness, inclusiveness, effectiveness, and hence legitimacy of the political system (Diamond, 1994). In the opinion of Informants 1 and 5 as per as democratic consolidation is concerned, CSO's are at the forefront in promoting the ideals of the process 
more than the political parties. According to them, in Nigeria, most of the political parties are becoming inactive and mute until a new election season. In the contemporary world opposition parties are the most distinctive features of democracy and the absence of which is regarded as the absence of democracy (Robert Dahl cited in Van Biezen \& Wallace, 2013), yet CSOs roles supersedes the former as it is the live wire of democratic movement from the beginning to the end (Thapa, 2016).

Moreover, CSOs are believed to be at the forefront of peace-building in the country. Informant 1, 2, 3 and 6 had attested to the fact that CDD, ACE and SDN have played immense roles in ensuring a conflict-free process of democratization which eventually led the process to unimaginable successes. In relation to peace-building, the CSOs have contributed extremely in promoting multiparty democracy because they have strengthened and removed the feeling of distrust and bitterness among political parties (Botchway, 2018). Through this the political parties come together and use the same platform to advance their party's manifestoes and interrelate with each other without any rancour. This indeed has made the democratic experiment in the country more meaningful and fruitful.

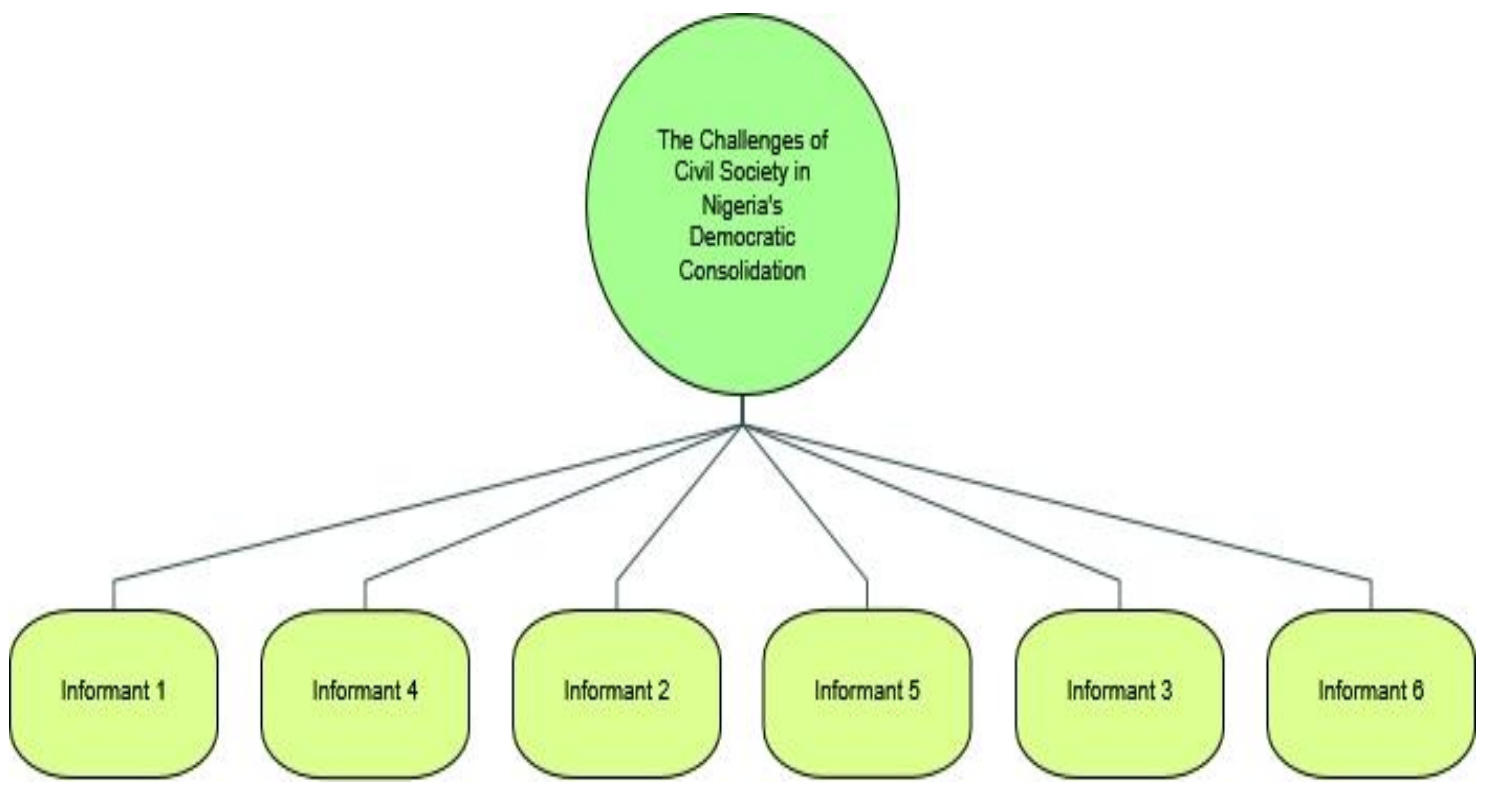

Figure 2. Diagram Showing the informants who responded on the Challenges Faced by CSOs on their Contribution to Democratic Consolidation in Nigeria

Source: Nvivo 12

According to informant 4, 5 and 6 one of the greatest challenges of civil society organization world over is that the political leaders and corporate interest scuttle their efforts because they see them as threats to their primitive accumulation. Sriskandarajah (2015) maintained that civil society suffers long lasting attacks in many countries because of the serious questions they upon ask about power, which the elites usually went to any length to get and maintain for personal aggrandizement. In short, CSOs face series of intimidations and attacks from the state forces who are always going against their activities This, indeed, make the civil society space a very tumultuous one and risk bearing which at times cost the lives of some actors.

Again, informants 1, 2 and 3 narrated that most of the CSOs are not ideologically based. According to them the CSOs in Nigeria are not doing things out of goodwill for they are sponsored by some specific agencies which made them to promote some certain ideologies. In such situations it is assumed that they are not working to promote politics or democratic consolidation. In addition, informant 2, 5 and 6 have lamented that one major setback affecting the CSOs themselves is that they are frequently silent in proactively affecting the people and the society at large except where the issue has become of a national topic. They have the tendency of relying on the state for information and direction to head-start on sensitive matters. These failures and many more of the CSOs made their activities in deepening democracy to remain in a serious doubt (Igbokwe-Ibeto, Ewuim, Anazodo \& Osawe, 2014; Botchway, 2018). 
Thirdly, additional greatest challenge opposing the CSOs in their drive towards democratic consolidation is lack of financial base. Informant 6 and 1 have attributed most of the failures of the CSOs to economic shortcomings. They argued that most of these associations do not have a strong economic means of survival and operations in Nigeria. This is in consonance with the opinions of Igbokwe-Ibeto, Ewuim, Anazodo and Osawe (2014) that:

The lack of financial autonomy of civil society compromises their independent approach to issues and ability to carry out long term plans and programmes. This perhaps explains why they could not insist on a new socioeconomic and political order in Nigeria prior to the return to civil rule. Also, with growing poverty in the land, members and the leadership of civil society are likely to capitulate in the face of the present economic realities that has pauperized majority of the political and economic elites. The poverty question therefore, is crucial to roles civil society can play in democratic consolidation in Nigeria (Igbokwe-Ibeto, Ewuim, Anazodo and Osawe, 2014:9).

Of course, it is argued that scarce financial muscles are a crucial drawback which stalled the actions of the CSOs in democratic consolidation process. This is especially the rationale behind being them mostly urban-based. Indeed, among the shortcomings of these associations is seen in being them mostly urban-based. Their presence in the rural areas is quite minimal. Informant 1 described that majority of the CSOs are urban-based; thus, their activities of democratic consolidation in the country is seriously limited because rural areas are the most populous part of the country where civic enlightenment is more required than the urban centres comparatively. Therefore, the direction of these associations is circumscribed to urban areas while important social forces in countryside are ignored (Mercy, 2012). And, neglecting the rural areas suffocates democratization by making the process more elitist hence injurious to consolidation of democracy.

\section{Summary}

In practical sense, civil society have been well acknowledged to be the greatest force in nurturing and maintaining democratic ideals in any society without which democracy might likely be at the verge of collapse. A robust and dependable civil society represent the interests of the people and serve as a check on the excessive use of power and primitive accumulation by the state actors. Indeed, the study revealed some signs of an increasing strength and boldness in civil society towards democratic consolidation in Nigeria. It revealed that CSOs are very central democratic actors in the process of democratization by monitoring numerous governmental or political activities in the country. Through monitoring the CSOs therefore challenge any policy move that is inimical to democratic principles which in effect improves the efficiency and success of democratic governance and its consolidation. It has also revealed that these CSOs engaged in advocacy programs that help in enlightening the public on the civic education and several policy programs of the state that aid in the betterment of the lots of the populace as clearly explained by the liberal democratic theory which emphasise the need for CSOs in the process of democratization. Moreover, the result shows that the three CSOs have a strength that aids them to take on certain things that other CSOs in Nigeria did not do.

\section{Conclusion}

The paper has discussed and analyzed the roles and challenges of CSOs in the consolidation of democracy in Nigeria's Fourth Republic by using liberal democratic theory as an explanatory framework. It therefore explained how these associations contribute in the democratic consolidation of the country through public enlightenment programs; influencing government policies and the advocacy for adherence to rule of law among others. Furthermore, it spelt out the challenging issues confronting the CSOs specifically on matters relating to inadequate financial resources; lack of national spread and external influences by international donor organizations respectively. It finally showcased the importance of these actors in consolidating democratic form of governance in Nigeria. It is therefore vividly clear from the foregoing that CSOs have become indispensable actors in the democratic consolidation of Nigeria despite the myriads of challenges bedeviling their activities. Thus, their need to become more actively vibrant in the democratic development has become significant, hence, greater need for recommendatory solutions become necessary.

\section{Recommendations}

So, it has become unarguably necessary for civil society actors to restructure their patterns and strategies in relating with government to provide a worthwhile checks and balances that would eventually consolidate democracy More so, funding is a crucial element in the organization and processes of civil society. CSOs should also learn and create a way of economic survival to reduce their dependence on foreign donor agencies who use such means to influence their activities by imposing their ideologies and philosophies upon them. The governments should encourage free 
civil society since it inspires governments to be more accountable, transparent, honest and responsive to the public needs, which will make it further win the support of the public and reinforce their legitimacy. This would allow civil society opposition actors to ventilate freely for the advancement of democratic consolidation in developing democracies. Moreover, CSOs should also strengthen partnership with other democratic stakeholders in a responsible and productive way that would further consolidate democratic integrity in Nigeria. It is also of paramount importance for civil society to extend their activities beyond urban centres to the rural areas. This would allow for an all-inclusive movement in consolidating democracy and its ideals in all the nook and crannies of the country to have national spread. The paper also suggested for further studies on CSOs whose activities seems to indirectly negate democratic consolidation in Nigeria.

\section{References}

Aduku, A. A. \& Umoru, Y. A. (2014). Political Parties and Democratic Consolidation in Nigeria's Fourth Republic. Journal, Global Science, Political Development, 2(3), 79-108.

Centre, European UK, Babbie, E. (2004). The practice of social research. Belmont, CA: Wads-Worth.

Brack, N., \& Weinblum, S. (2011). Political Opposition": Towards a Renewed Research Agenda. Interdisciplinary Political Studies, 1(1), 69-79. Retrieved http://scholar.google.com/scholar?hl=en\&btnG=Search\&q=intitle:?Political+ Opp osition?:+Towards+a+Renewed+Research+Agenda\#0.

Botchway, T.P. (2018). Civil Society and the Consolidation of Democracy in Ghana's Fourth Republic. Cogent Social Sciences. $\quad$ https://doi.org/10.1080/23311886.2018.1452840.

Creswell, J. W. (2013). Qualitative Inquiry \& Research Design: Choosing among Five Approaches. (3rd ed.). Thousand Oaks, CA: SAGE.

Dahl, R. A. (1971) Polyarchy: Participation and Opposition. New Haven: Yale University Press.

Diamond, L. (1994). Toward Democratic Consolidation. Journal of Democracy, 5(3), $\quad 4-\quad 17$. https://doi.org/10.1353/jod.1994.0041.

Ibietan, J. \& Ajayi, O. O. (2015). The Governing Elite and Democratic Consolidation in Nigeria: An Appraisal of the Fourth Republic. Journal of Human and Social Science Research, Vol. 6 (1). pp. 14-21.

Ibogkwe-Ibeto, C.J. et al (2014). Civil Society Organizations and Democratic Consolidation in Nigeria: Issues, Challenges and the Way Forward. Journal of Sustainable Development in Africa,Vol. 16, No.5.

Islamoglu, H. (2001). Civil Society, Concept and History. International Encyclopedia of the Social \& Behavioral Sciences (Vol. 3). https://doi.org/10.1016/B0-08- 043076-7/02678-4.

Jamali, S. Hasan, H. and Ching, L. C. (2016). Digital Engagement, Political and Civic Participation: Mobilizing Youth in Marginalized Communities. Journal of Business and Social Review in Emerging Economies, 2 (1), 31-40. DOI: $\quad$ https://doi.org/10.26710/jbsee.v2i1.16.

Kopecky P. \& Spirova M. (2008). Power of the Powerless: Parliamentary Opposition in Eastern Europe, The Journal of Legislative Studies 14(1/2): 133-159.

Kwasau, M.A. (2013), The challenges of Democratic Consolidation in Nigeria's Fourth

Republic. European Scientific Journal, March edition, vol. 9 (8).

Lee, S. (2007). Democratic Transition and the Consolidation of Democracy in South Korea. Taiwan Journal of Democracy, Volume 3 (1).

Linz, J. \& Stepan, A. (1996). Problems of Democratic Transition and Consolidation Europe, South America, and Post-Communist Europe. Yale: JHU

: Southern

Press.

Markus, M. R. (2001). Decent Society and/or Civil Society? Social Research, 68(4). 10111030.Retrievedfromttp://search.ebscohost.com.subzero.uelph.ca/login.asp $\mathrm{x}$ ?direct $=$ true $\& \mathrm{db}=\mathrm{bth} \& \mathrm{AN}=6009770 \&$ site $=$ ehost-live $\&$ scope $=$ site.

Mercy, A.O. (2012). Civil Society and Democratic Consolidation in Nigeria. Journal of Emerging Trends in Educational Research and Policy Studies $\quad$ (JETERAPS) 3 (1): 61-67.

Mohammed, U (2013), Nigeria's Elected System: A change to Sustainable Democracy in the Fourth Republic. International Journal of Innovative Research and Development, Pp. 567- 581. Available at www.ijird.com 
Nuhu, I. (2011). Democratic Consolidation in Africa: The Role of Civil Society B.Sc. Thesis Submitted to the University of Applied Social

Department of Social and Cultural Sciences, Ghana.

Sciences,

Organisations.

O’Donnell, G. (1992). "Transitions, Continuities, and Paradoxes," Issues in Consolidation. In: Mainwaring, S. et al. (eds.), The New South Comparative Perspective, (Notre Dame:

American $\quad \begin{aligned} & \text { Democratic } \\ & \text { Democracies in }\end{aligned}$ University of Notre Dame Press) 17-56.

Schedler, A. (1998). What is Democracy? Journal of Democracy, 9 (2) 91-107.

Sriskandarajah, D. (2015). Civicus: State of Civil Society Report. Published by Civicus: $\quad$ World Alliance for Citizen Participation.

Svolik, M. W.(2015). Equilibrium Analysis of Political Institutions. Routledge

Handbook of Comparative Political Institutions, 87-97.

Thapa, B. E. P. (2016). An Ambivalent Civil Society in Democratic Consolidation - The Case of Local Chambers of Commerce and Industry in the Visayas and North Mindanao, 138(Januar), 70-88.

Van Biezen, I., \& Wallace, H. (2013). Old and New Oppositions in Contemporary Europe. Government and Opposition, 48(Special Issue 03), 289-313. https://doi.org/10.1017/gov.2013.11.

World Bank. (2013). Defining Civil Society. Www.Worldbank.Org, 86-94. Retrieved fromhttp://web.worldbank.org/WBSITE/EXTERNAL/TOPICS/CSO/0,,conten

0101499 menuPK:244752 pagePK:220503 piPK:220476 theSitePK:228717 ,00 $\quad$.html.

Yin, R. K. (1984). Case Study Research: Design and Methods. Beverly Hills, CA: Sage.

Zaidise, E. (2004). The Role of Civil Society in Developing and Consolidating Democracy: Evidence from Israel. European Consortium for Political Research Joint-Sessions of Workshops Uppsala, Sweden, April 13-18, 2004 